\title{
North Side Revolutionaries in the Civil Rights Struggle: The African American Community in Des Moines and the Black Panther Party for Self-Defense, 1948-1970
}

\author{
BRUCE FEHN AND ROBERT JEFFERSON
}

ON ONE FATEFUL EVENING during the mid-1960s, black power politics and civil rights activism shared equal billing in Des Moines, Iowa. On July 4, 1966, young African Americans assembled at Good Park, in Des Moines's largest black neighborhood, and participated in a violent disturbance lasting several hours. According to Des Moines Register reporters Dick Spry and Stephen Seploy, "the clash between youths and police apparently [had] been brewing for several nights. Negro youths, on several occasions [had] refused to leave the park swimming pool at closing time." The night before the riot, young African Americans were upset by what they perceived as two policemen's rough handling of two youngsters in the park after the 10 o'clock curfew. The Independence Day festivities with fireworks, which were illegal in Iowa, disturbed a neighbor, who called po-

We thank two anonymous reviewers for helpful comments and suggestions. Thanks also to Marilyn Upchurch for research assistance at the downtown Des Moines Public Library. Hal Chase supported us from the beginning of the project and set up interviews with Charles Knox and Sister Haadasha. Thanks to Phil Parks for putting us in contact with John Estes. We are also grateful for the support of a 2007-2008 State Historical Society of Iowa Research Grant.

THE ANNALS OF IOWA 69 (Winter 2010). (C) The State Historical Society of Iowa, 2010. 
lice. When police arrived on the scene, some 200 July 4 revelers turned into race rebels. Young people jumped on the police cars and rocked them back and forth. They barricaded the park entrance with benches and a trash barrel. As police tried to remove the barricade, rioters hurled rocks and bottles at them. ${ }^{1}$

To quell the Good Park uprising, Wendell Nichols, the white acting police chief, called upon three prominent leaders in the African American community to help settle the disturbance: John Estes, Perry Hooks and James B. "Brad" Morris. Estes, a funeral home director, was known for his work with young people in the black community. In 1968 he became president of the Des Moines branch of the National Association for the Advancement of Colored People (NAACP). Hooks was director of the Des Moines Human Relations Commission, and Brad Morris was head of the Des Moines NAACP at that time. Well known among youth in the African American community, they succeeded in convincing the young people to disperse. The July 4 rioting, however, had not exhausted their discontent. The next evening, at 9:30 p.m., another disturbance shook the neighborhood. Again, police enlisted assistance from Estes and Morris. This time someone threw a brick and hit Morris in the ribs. After a sweep through the park and neighborhood, police arrested five men and two women, all 18 or 19 years of age. ${ }^{2}$

The July 1966 Good Park riots were a prelude to the emergence in Des Moines of a new, more radical politics, later mobilized by members of the Des Moines chapter of the Black Panther Party for Self-Defense. This more radical politics had historical roots in the city's racist history and African American efforts to overcome it. Leaders of Des Moines's black community had for years worked to end segregation, police harassment, and employment discrimination. In the 1940s and '50s, for example, black attorneys, including Charles P. Howard Sr. and Robert Wright Sr., had defended African Americans who felt that they had been treated unfairly by police, businesses, or the judicial system. In the most famous civil rights action in Iowa history, Edna Griffin and others used direct action tactics to desegregate

1. Des Moines Register, 7/5/1966.

2. Iowa Bystander (hereafter cited as Bystander), 7/7/1966. 
the Katz drug store. ${ }^{3}$ Community organizers in the 1950s and '60s challenged white landlords' and realtors' segregated housing practices. Black leaders, such as John Estes, provided young African Americans with places to go and things to do.

What some African American leaders at the time saw in the July 1966 Good Park insurrections as "defiance of law and order" perpetrated by a "few misguided youngsters" was in fact a watershed moment in the city's racial politics. Simmering frustrations associated with racial discrimination in housing, education, and employment and de facto segregation of swimming pools and other public facilities boiled over into demonstrations demanding recreational space where African Americans could comfortably assemble and socialize. ${ }^{4}$ With the 1966 Good Park riots, young African Americans began a process of bold and public agitation to secure changes in their neighborhoods, including defense of the park and the near north side black neighborhood from police intrusions. Over the next five years, young African Americans' many subsequent confrontations with police and city officials reshaped a much longer African American movement advocating social change and justice in Iowa's capital city.

Out of the crucible of earlier struggles against racism, as well as young people's mid-'60s run-ins and confrontations with police, emerged the Des Moines chapter of the Black Panther Party for Self-Defense (BPP). It harnessed and organized the energy of post-World War II black discontent and gave it a militant charge. Although the Des Moines BPP chapter as an organized group lasted only from June 1968 to January 1970, the organization had a significant impact on Des Moines's economic, political, and social landscape - an impact that can only be understood within the longer context of African American history in Des Moines.

3. Noah Lawrence, "'Since it is my right, I would like to have it': Edna Griffin and the Katz Drug Store Desegregation Movement," Annals of Iowa 67 (2008), 298-330; idem, "Griffin, Edna Mae Williams," in The Biographical Dictionary of Iowa, ed. David Hudson et al. (Iowa City, 2008), 196-97; Bruce Fehn, "Howard, Charles P.," ibid., 253-54. On Wright, see Alfredo Parrish, "The Legacy of Black Attorneys in Iowa," in Outside In: African-American History in Iowa, 1838-2000, ed. Bill Silag et al. (Des Moines, 2001), 281.

4. Edward S. Allen, Freedom in Iowa: The Role of the Iowa Civil Liberties Union (Ames, 1977), 99-104. 
The Des Moines Panthers mined discontent that had been festering for a century in the city's African American community. In the wake of World War II, however, African Americans sharply intensified demands for equal opportunity and an end to de jure and de facto segregation. After fighting fascism as soldiers in the European and Pacific theaters of the war, as well as wartime discrimination on the home front, they were ready to mobilize against white-dominated institutions that were keeping them down. Between 1948 and 1968, under the leadership of John Estes, Edna Griffin, Brad Morris, and many others, the civil rights movement attained increasing momentum, power, and influence. That power and influence, however, were never sufficient to overcome white residents' determination to keep blacks out of their neighborhoods or overturn white employers' tendency to discriminate against blacks in hiring and job placement.

As historian Yohuru Williams has observed, objective assessment of the BPP requires appraisal of its "relationship not just to the civil rights movement but also to Black Power and its influence in the late 1950s and 1960s." Fully realized histories of local chapters also require fine-grained analysis of local historical conditions and actions, which set the stage for each branch's particular development. In recent years historians have taken us beyond the widely held view of the party as anti-white and wedded to a politics of armed self-defense of the black community. Historians now recognize that the national party, and its individual chapters never "espoused blanket antiwhite racism as their critics allege. Instead, they formed alliances with white radicals even as they touted armed revolution and promoted community service programs." ${ }^{5}$

Historian Reynaldo Anderson correctly observed that the Des Moines chapter forged practical programs to address circumstances faced by the city's black residents. ${ }^{6}$ A more complete history of the Des Moines chapter, however, must attend

5. Yohuru Williams, "'Some Abstract Thing Called Freedom': Civil Rights, Black Power, and the Legacy of the Black Panther Party," OAH Magazine of History 22 (2008), 18.

6. Reynaldo Anderson, "Practical Internationalists: The Story of the Des Moines, Iowa, Black Panther Party," in Groundwork: Local Black Freedom Movements in America, ed. Jeanne Theoharis and Komozi Woodard (New York, 2005), 284. 
to the development of African American efforts to survive and thrive under particular local conditions of racism, discrimination, and segregation. Local BPP leaders, most of them reared in Des Moines, understood local circumstances, and their political and community programs emerged from that understanding.

Anderson, in his study, pointed out how urban renewal seriously disrupted black life and created conditions for the Des Moines Panthers' emergence. Yet Anderson neither specified the nature of those disruptions nor connected the Panthers' politics to African Americans' previous and ongoing struggles against discrimination and segregation. While the Black Panthers, with their militant rhetoric, confrontational behavior, and independent survival programs, gave a radical shove to black politics, they also built programs upon extant political and economic resources. In Des Moines, moreover, Black Panthers found traditional African American leaders, and even members of the white community, who were sympathetic to their survival programs, cultivation of black pride, and forceful challenges to a racist society that segregated and oppressed African Americans.

IN THE FACE OF WHITE RACISM, discrimination, and segregation, the previous generation of African Americans in Des Moines had built their own institutions, organizations, and lifestyles in the city's segregated urban landscape. In the 1950s, in a city of 205,000 residents, of whom roughly 20,000 were African American, the focal point of black economic, social, and cultural life was on or near Center Street. There black-owned businesses served mostly black customers, with a few whites occasionally going there for the good music to be found in bars and clubs. Urban renewal and the Des Moines freeway construction in the early 1960s, however, led to Center Street's disintegration as the hub of black business and culture. For decades, Center Street's businesses and entertainment venues had served and supported the black community. Until its demise, Center Street was the place for African Americans to get their hair cut or styled, dine at a good restaurant, visit the pharmacy, or socialize. Black citizens submitted orders for flyers, directories, business cards, and menus at Hobart DePatten's print shop. Women trained as beauticians at Pauline Brown Humphrey's Crescent School 
of Beauty Culture. The Center Street neighborhood provided many opportunities to enjoy music at the Billiken, 1113, and Sepia nightclubs, among several others. During Center Street's heyday, in the 1930s and "40s, the neighborhood "brimmed with activity," wrote journalist and historian Raymond Kelso Weikal. "And its music flowed like flood waters."

For white residents of Des Moines, "Center Street" was synonymous with the black part of town. Although "a lot of whites" went to Center Street to hear good music at its nightclubs, few entered the neighborhood for other purposes. ${ }^{8}$ As freeway construction and urban renewal displaced mainstream black businesses, however, some whites went to Center Street to pursue illegal activities. Underage whites found places or individuals that would sell them beer or liquor. Prostitution began to take hold, and the Des Moines vice squad became a regular presence in the area. According to Hobart DePatten Sr., who lived just a few blocks from Center Street, police would no longer "cut you a break," but would arrest people for the most minor offenses. ${ }^{9}$

The Des Moines white establishment's decisions in the late 1950s to begin urban development projects, including freeway construction, drove daggers into the Center Street neighborhood. DePatten, whose father for many years ran a printing business on Center Street, expressed the magnitude of the disaster for many of Des Moines's black residents: "Urban renewal was our 9/11."10 Urban renewal projects and the new freeway wiped out affordable housing for black families. White realtors worked with white residents to keep displaced African Americans from moving into white neighborhoods. As a result, blacks found themselves ever more tightly confined within the deteriorating near north side neighborhood. ${ }^{11}$ White citizens, moreover, enforced segregation

7. Jack Lufkin, “'Higher Expectations for Ourselves': African-Americans in Iowa's Business World," in Outside In, 205-9; Raymond Kelso Weikal, "The Song of the River: Black Music and Entertainment in Iowa," ibid., 530; Tom Gary, "A Place Called Center Street," Straight Ahead (Winter 2007), 1, 3.

8. Weikal, "The Song of the River," 533.

9. Hobart DePatten, interview with authors, 8/8/2008, Des Moines.

10. Ibid.

11. Iowa State Advisory Committee to the United States Commission on Civil Rights, Urban Renewal Programs and Their Effects on Racial Minority Group Housing in Three Iowa Cities (Washington, DC, 1964), 3-12. 
by means of verbal and sometimes physical intimidation. There was at least one case of a front yard cross burning when an African American moved into a white neighborhood. In the mid1960s, even well-off, professional African Americans encountered "institutional racism designed to keep blacks both literally and figuratively 'in their place.'" And, of course, whites of all ages reinforced their own sense of superiority through racist jokes and taunts directed at Des Moines's black citizens. ${ }^{12}$

Small wonder, then, that young African Americans cherished Good Park as a social and recreational space more or less isolated from the racism and discrimination that permeated the city. Good Park was one place where black children and teenagers went to play, socialize, and recreate. The park was roughly a square block of green space with a wading pool, shelter house, and basketball courts. Located near the west end of Des Moines's black neighborhood, the park was bordered on the south by the Des Moines freeway. On the north, the park sloped down to University Avenue, a busy east-west city thoroughfare. To the park's immediate west, along and near 17th Street, was an integrated working-class neighborhood that was increasingly African American in composition. To the east a steep incline dropped down to Keosauqua Avenue, a busy street that cut northwestsoutheast through the African American community. Historian Ralph Crowder, who grew up near Good Park, remembered it as a "wonderful Black institution in Des Moines." Crowder observed that in the 1950s and early 1960s both blacks and whites "accepted what now would be called segregated spaces without any problems." He remembered Good Park in those years as

a wonderful setting where Black athletic traditions were passed on to younger generations. Shared historical information usually was passed on to younger Black men from as far back as 1940s.... Basketball and swimming were the major formal activities. ... In the mid and late 1950s, the Good Park Pool was the center of our young social circle. This is where young Black boys learned how to swim, dive, court women, and developed strong bonds of friendship. . . . As we grew older, Good became an all purpose social center that embraced so much of my preteen and teen years.

12. Bystander, 9/7/1967; Steven Berry and Erin Herndon, "Healing Hands, Questing Hearts: African-American Physicians in Iowa," in Outside In, 243-44. 
.. . There were certainly problems and some folks had clashes with racist white cops. But my generation and close friends who went to North [High School] all longed for some athletic accomplishments rather than anything that had to do with gang culture.

For Crowder, Good Park, like black churches, was a treasured social space that "filled Black male youth with some solid options." ${ }^{13}$

The "solid options" Good Park and black institutions provided proved insufficient to stem the tide of growing black discontent. When two Des Moines Register reporters investigated the 1966 riot's sources, teenagers and young adults told them that there was not enough for them to do at night. Some complained of the inability to find jobs; others expressed concern about rough police treatment. Young African Americans told John Estes that when police officers approached them, "they should approach as a gentleman and not with 'Boy' or 'Hey, you.'" One 19-year-old told reporters that the Good Park riots began when young people in the park were having a party after the 10 p.m. curfew and "a couple of police came in with nightsticks. One grabbed a kid, called him names and pushed him. ${ }^{14}$

The 1966 Good Park riots occurred at a time when perceptions of police brutality were sparking riots in many American cities. African Americans, many stuck in northern urban ghettos with few economic opportunities, grew impatient with the slow progress of the mainstream civil rights movement. In 1964 blacks rioted in Chicago, Philadelphia, Harlem, Jacksonville, Florida; Rochester, New York; and Newark, Patterson, and Keansburg, New Jersey. In 1965 even larger riots occurred in the Watts area of Los Angeles and again in Chicago. More racial disturbances took place in 1966, the year of the Good Park riots, including one just 150 miles west of Des Moines in Omaha, Nebraska. Two years later, on July 7, 1968, a race riot broke out just 100 miles northeast of Des Moines in Waterloo, Iowa. ${ }^{15}$

13. Weikal, "Song of the River," 529; Ralph Crowder to Bruce Fehn, e-mail correspondence, 8/19/2008.

14. Des Moines Register, $7 / 7 / 1966$.

15. Peter M. Bergman, The Chronological History of the Negro in America (New York, 1969), 584-99, passim; Des Moines Register, 7/5/1968; Bystander, 7/13/ 1968. For more on the urban disturbances of the period, see Report of the $\mathrm{Na}$ tional Advisory Commission on Civil Disorders (New York, 1968), 19-131. 
As in other cities, a police confrontation with disaffected young people triggered the July 1966 Good Park riots, and police became a focal point of African American anger. ${ }^{16}$ Blacks in Des Moines distrusted the city's predominantly white police force. ${ }^{17}$ In wide circulation among blacks at the time were accounts of police mistreatment of prisoners in the elevator carrying those arrested from the parking lot behind the Polk County courthouse up to the "drunk tank" and jail cells. ${ }^{18}$ Blacks' resentment of police deepened when police made arrests in the black community or even killed an African American. For example, just one month after the Good Park riots, on August 15, 1966, patrolman Charles Park shot dead Dwight Green, who allegedly had refused Park's order to halt as he was leaving through the window of a laundry that had closed for the day. Four days later, an integrated group of young people marched on Des Moines police headquarters, demanding that police form a "grievance board" and establish stringent rules regarding the use of highly lethal "riot guns" of the kind that killed Dwight Green. Once assembled, the crowd taunted police. Soon African Americans formed the "Citizens Committee to End Police Brutality." "Organized at Good Park," the African American newspaper the Bystander reported, "its first aims are the removal of shotguns from patrolman's cars and a review board to investigate such police violations as shotgunnings, mis-arrests and 'trips up the elevator.' "'19

These events in 1966 took place at the same time as black power rhetoric infused black neighborhoods - rhetoric that aggravated the city's white population. Just a few weeks before

16. Between 1963 and 1969, tensions between black youths and police in other areas such as Wyandanch and Nyack, New York; Massillon and Sandusky, Ohio; and Plainfield, Rahway, Livingston, Elizabeth, East Orange, Paterson, Irvington, Jersey City, and Montclair, New Jersey, often resulted in looting and arson and millions of dollars worth of damage. For more on this, see Thomas J. Sugrue, Sweet Land of Liberty: The Forgotten Struggle for Civil Rights in the North (New York, 2008), 325-26.

17. In 1968 six African Americans worked in the Des Moines Police Department out of a total 270 employees (less than 3 percent). "Non-whites" in Des Moines composed 5.5 percent of the total population. Des Moines Register, 12/5/1968.

18. Bystander, 8/25/1966.

19. Bystander, 8/18/1966, 8/1/1966, 8/25/1966. 
Green's death and the subsequent demonstration at police headquarters, the Des Moines Register, the city's most widely circulated newspaper, editorialized that the use of the term black power by the Student Non-Violent Coordinating Committee and the Congress of Racial Equality aroused "angry belligerence ... among those who accept it and anger and misunderstanding among those (white and black) who oppose it." The editorial sympathized with African Americans who suffered at the hands of "Kluxers and cruising shotgunners" in the Deep South, "but making it sound like revolutionary violence doesn't help a bit." ${ }^{20}$

Des Moines's traditional black leaders, in contrast, came to understand the appeal of a more confrontational brand of rhetoric and politics. They recognized the disaffection of young blacks who were "denied voices and . . . aligned themselves . . . with so-called militant groups." ${ }^{21}$ In Des Moines, racism, segregation, and discrimination remained intractable. At least some African Americans thought that white police in the mid-1960s had become increasingly aggressive in arresting black citizens. ${ }^{22}$ For blacks, residential segregation was intensified by varieties of de facto segregation in schools, public accommodations, and neighborhoods where African Americans were not welcome.

African American discontent reached a boiling point in the two years following the first Good Park riot. In 1967 those displaced by Interstate 235 freeway construction and the accompanying urban renewal projects grew upset with the Des Moines City Council for failing to provide for good housing and smooth relocation procedures. Brad Morris and W. Lawrence Oliver, attorneys for displaced residents, accused the council of designing a "planned program of segregated housing." Displaced persons also were angry about low appraisals for homes and businesses, especially such businesses as the Crescent beauty shop, Wells Billiard Parlor, and Hardaway's Tonsorial Parlor. On March 27, 1967, home and business owners complained before a Des Moines City Council meeting that the city had not offered residents enough to buy comparable homes elsewhere. They

20. Des Moines Register, $7 / 7 / 1966$.

21. Robert A. Wright Sr. to Gloster B. Current, 9/25/1970 (microfilm), part 29, series A, reel 14, NAACP Papers.

22. DePatten interview. 
charged that the "secretive" appraisal process aroused suspicions among displaced persons. One of the African Americans at the city council meeting "wanted to know about a person who had struggled to buy a house and lived there 40 years, only to, in Urban Renewal, have to pull up his roots and accept a price that would not let him buy another such dwelling comparable to the first." J. Taylor worried specifically about elderly displaced residents who had to relocate. Taylor gave sharp expression to elderly residents' anxieties when he told the council, "It would be a lot more human if you took them out and shot them." ${ }^{23}$

The black community also had grown increasingly frustrated with employment discrimination in Des Moines. As measured by the Bystander's coverage of hiring discrimination, that was a major and long-festering issue within the black community. In 1967, for example, African Americans were angry that the fire department refused to hire qualified black applicants. In April the department rejected applications from Mulford Fonza and Walter Williams, prompting the Bystander to refer to city officials as "jack asses" for "managing to block the appointment of any Negroes to the fire department." Finally, "after over a year's hassle between the Civil Service Commission, the Des Moines Human Rights Commission, [and] the Civil Rights Commission," reported the Bystander, "Milford Fonza, 22, was accepted and certified as a fireman." Labor unions, such as the local plumbers and bricklayers unions, also blocked African Americans from entering apprenticeship programs. Such discriminatory practices deeply angered members of the black community. ${ }^{24}$

African American community leaders were also frustrated as entrenched white city officials blocked legitimate avenues for rectifying employment discrimination. Although African American Perry Hooks, director of the Des Moines Civil Rights Commission, was able to apply pressure to various Des Moines agencies to address employment discrimination, the Des Moines Civil Service Commission refused to include any African Americans among its membership. When in April 1967 the commission appointed a new member, it chose a white appli-

23. Bystander, 3/30/1967. See also Bystander editorials in the same issue and 4/27/1967.

24. Bystander, 4/13/1966, 5/18/1967, 4/20/1966. 
cant over three key leaders of the Des Moines black community: John Estes Jr., president of the Des Moines branch of the NAACP, Robert A. Wright Sr., the Iowa state NAACP president, and attorney James B. Morris Jr. ${ }^{25}$

The assassination of Dr. Martin Luther King Jr. on April 4, 1968, heightened African Americans' indignation and sparked riots in at least 125 cities across the nation. ${ }^{26}$ In Des Moines, four days after the shooting, African Americans and some white allies marched to a demonstration at the state capitol. June Franklin, a black woman who represented the black area near Good Park in the state legislature, delivered a powerful message infused with the rhetoric of black power. Franklin proclaimed,

It is time for the few black citizens of Iowa who sit on policymaking boards and commissions, or hold jobs where they can help their black brothers to stop compromising, stop scratching, stop shuffling, stop grinning, stop accepting half a loaf, stop being handkerchief heads and Uncle Toms ... to stand up and step forward and be counted. Let's pray together, march together, work together. Let us all be black together. Dr. King never accepted half a loaf. He was never an Uncle Tom. He walked in peace and fought for the dignity and equality of people. It is time for the black ministers of this city and state to stand up and step forward and show leadership - start leading our people into the promised land. ${ }^{27}$

Thirteen years later, in a 1991 interview, Representative Franklin asserted that it was the Black Panther Party that finally moved Des Moines's white elites to attack housing discrimination in the city. "It scared the pants off those people," Franklin claimed. "Business people, I guess they had visions of Des Moines burning down and all that kind of thing, that they'd never had before. . . . I think they got together and decided, hey, we don't want this for Des Moines, and I think they [the Panthers] helped bring it about, the change in attitude."

25. Bystander, 4/20/1967.

26. Bergman, Chronological History of the Negro, 609-10.

27. Quoted in Suzanne O'Dea Schenken, Legislators and Politicians: Iowa's Women Lawmakers (Ames, 1995), 118. See also Des Moines Register, 4/8/1968.

28. A. June Franklin, interview with Suzanne O’Dea Schenken, June 1991, box 2, "A Political Dialogue: Iowa's Women Legislators," Iowa Women's Archives, University of Iowa Libraries, Iowa City. 
As Representative Franklin cajoled black leaders to take strong action, young African Americans heeded the call and organized resistance to what they perceived as racially motivated policing of the black community. On June 5, 1968, several weeks before the Des Moines BPP's formal incorporation, roughly 35 young African Americans demonstrated at the Des Moines City Hall to support Stanley Lee Williams, whom police had arrested following a disturbance at 9th and University in the heart of the near north side black neighborhood. The demonstrators carried signs reading "Get the Police Off University Avenue," "Stop Police Brutality and Oppression," "Our Human Rights Have Been Violated We Demand Freedom Now," "Get Those Racist Cops Out of University [Avenue]," "Racist Cops and Government Are Guilty of Black Genocide," and "Black Control of the Black Community." ${ }^{29}$

With demonstrators using expressions such as "black genocide," "racist police," and "black control," Des Moines Register reporters sought the police department's views on what appeared to be a rapidly deteriorating relationship between near north side blacks and members of the police force. A policeman interviewed at the scene of the June 5 demonstration reported that a number of University Avenue area residents had called to support police patrols of the area. He said that the police wanted to recruit more black officers, and the department's "mobile recruiting unit had been in the area to try and enlist blacks into the police force." That statement, which could be interpreted as representing a police effort to reach out to the black community, contrasted sharply with what Acting Police Chief Wendell Nichols told the Register reporters. In response to black demands that police stay out the black community, Chief Nichols said ominously, "I can tell you one thing. We're not moving out of University Avenue."

MARTIN LUTHER KING'S MURDER, black frustrations, wide circulation of black power rhetoric, and a deepening chasm between blacks and police all together made conditions ripe for

29. Des Moines Register, 6/6/1968.

30. Ibid. 
the emergence in July 1968 of a Des Moines chapter of the Black Panther Party. Young African Americans in Des Moines had already demonstrated readiness for a more confrontational brand of politics. Traditional black leaders, moreover, became more sympathetic with the rhetoric of black pride and black power. ${ }^{31}$ Into this situation stepped Mary Rhem and Charles Knox, who already had prepared themselves to channel African Americans' discontent into a new politics and the establishment of new community-based programs.

Rhem and Knox had joined a revolutionary organization established on March 22, 1966, in Oakland, California: the Black Panther Party for Self-Defense. Panther organizations had already emerged in Harlem and a couple of other cities. However, the Oakland BPP became the recognized center of party ideology, politics, and image. While working to organize programs in Oakland's black communities, the headquarters published the Black Panther Intercommunal News Service, edited by David Hilliard, which the Oakland chapter distributed to other branches throughout the nation. Although individual chapters remained fiercely independent and focused on local concerns, the paper gave Black Panthers in other cities a shared identity and contributed to the party's nationwide image as a group determined to exert economic and social power in their own communities. The Oakland party's highly successful distillation of Panthers' intentions into its famous ten-point program also helped the Oakland chapter emerge as the ideological hub for chapters nationwide. ${ }^{32}$ With the national media's attention riveted on the Oakland chapter, its members' famous disruption of the California legislature on May 2, 1967, as well as Huey Newton's arrest and trial for murder and the subsequent "Free Huey" campaign, the Oakland party attained sufficient political caché to officially sanction formation of BPP chapters throughout the United States. Among these was the new chapter formed in the small midwestern city of Des Moines, Iowa.

31. Phil Parks, interview with authors, 8/8/2008, Des Moines; John Estes, interview with authors, 8/8/2008, Des Moines.

32. Deirdre Mullane, ed., Crossing the Danger Water: Three Hundred Years of African-American Writing (New York, 1993), 683-85. 
By 1967, Mary Rhem and Charles Knox had concluded that the North's segregated cities needed a new breed of African American leader to organize community members in programs for economic survival. Born in Arkansas, Rhem moved with her mother to Des Moines at age nine. They settled in Des Moines's near north side neighborhood. Inevitably, she soon felt the sting of racism and prejudice. A graduate of Des Moines North High School, Rhem, at age 19 in early 1968, went to Los Angeles to visit her brother. Together, they attended a BPP rally, which inspired Rhem to attend political education sessions. By July that year, Rhem was back in Des Moines, mobilizing African Americans into a Des Moines chapter of the Black Panther Party. ${ }^{33}$

As she walked the streets of her north side neighborhood, near the corner of 13th and University, Rhem ran into Charles Knox. She knew virtually everyone in her neighborhood, so she was immediately curious about this stranger, who was obviously engaged in some kind of street organizing. Rhem soon learned that she and Knox had a lot in common. Knox, whose confrontations with police and court appearances soon would make him notorious in Des Moines, had come from Chicago to Des Moines as part of the anti-poverty program, VISTA (Volunteers in Service to America). VISTA workers had a demonstrated record of organizing poor black communities, especially in the area of welfare rights. ${ }^{34}$

Soon after their first encounter, Rhem and Knox accelerated their recruitment efforts in the black community. On July 18, 1968, the "Black Panther Organization, Inc." submitted to the Iowa secretary of state's office articles of incorporation for the establishment of a permanent organization to "promote, implement and develop the well being of the entire black community in Iowa." Its application for incorporation included the names of 12 "initial directors," three women and nine men. Executing the articles before a notary public were Rhem, Knox, and Michael Harris, who also became a central figure in the Des Moines Panthers. In the articles the authors expressed their in-

33. Sister Haadasha and Charles Knox, joint interview with authors, 10/13/ 2007, Des Moines.

34. Frances Fox Piven and Richard A. Cloward, Poor People's Movements: Why They Succeed, How They Fail (New York, 1979), 292, 293. 
tention to "promote and develop black power in the community which means the economic, political and cultural control of the black community by black people." Except for Harris, who lived on 28th Street, the other party directors lived very close to one another, between 11th and 19th streets, in the heart of Des Moines's near north side black community, near the chapter's registered office on University Avenue. ${ }^{35}$

Rhem was the undoubted founder of the BPP in Des Moines, but Charles Knox became the public face of the organization. The BPP in Des Moines, as elsewhere, was a masculinist organization, with talented women exerting leadership behind the scenes developing programs to benefit black community members. Rhem, as head of the Des Moines BPP, set about the practical, hard work of organizing breakfast programs for children and health programs for adults. ${ }^{36}$ She made connections, for example, with Joeanna Cheatom, who had founded a welfare rights group called the Black Mobile Street Workers. ${ }^{37}$

Knox, too, worked hard at organizing party programs and making connections with community groups, but he also caught the ears and eyes of public officials, including the Des Moines police, with his militant voice and highly visible political theater. He was often the subject of local newspaper stories. In one article, the Des Moines Register published a lengthy account of Knox's work with a breakfast program. In others, the Register reported how the public variously regarded Knox, with some viewing him as an honorable individual committed to the black community and others seeing him as a phony who played upon "white guilt" to squeeze dollars from "liberals." Most of all, articles reported on crimes and court cases involving Knox,

35. Hearings before the Committee on Internal Security, Black Panther Party, Part Four: National Office Operations and Investigation of Activities in Des Moines, Iowa, and Omaha, Nebraska, 91st Cong., 2nd sess., 10/6-15 and 11/17/1970 (Washington, DC, 1971), 5009-11.

36. For broader discussions of gender politics within the BPP during the period, see Tracye Matthews, "'No One Ever Asks What a Man's Place in the Revolution Is': Gender and the Politics of the Black Panther Party, 1966-1971," in The Black Panther Party Reconsidered, ed. Charles E. Jones (Baltimore, 1998), 267-304; and Angela D. LeBlanc-Ernest, " 'The Most Qualified Person to Handle the Job': Black Panther Party Women, 1966-1982," ibid., 305-34.

37. Hearings before the Committee on Internal Security, 4834. 


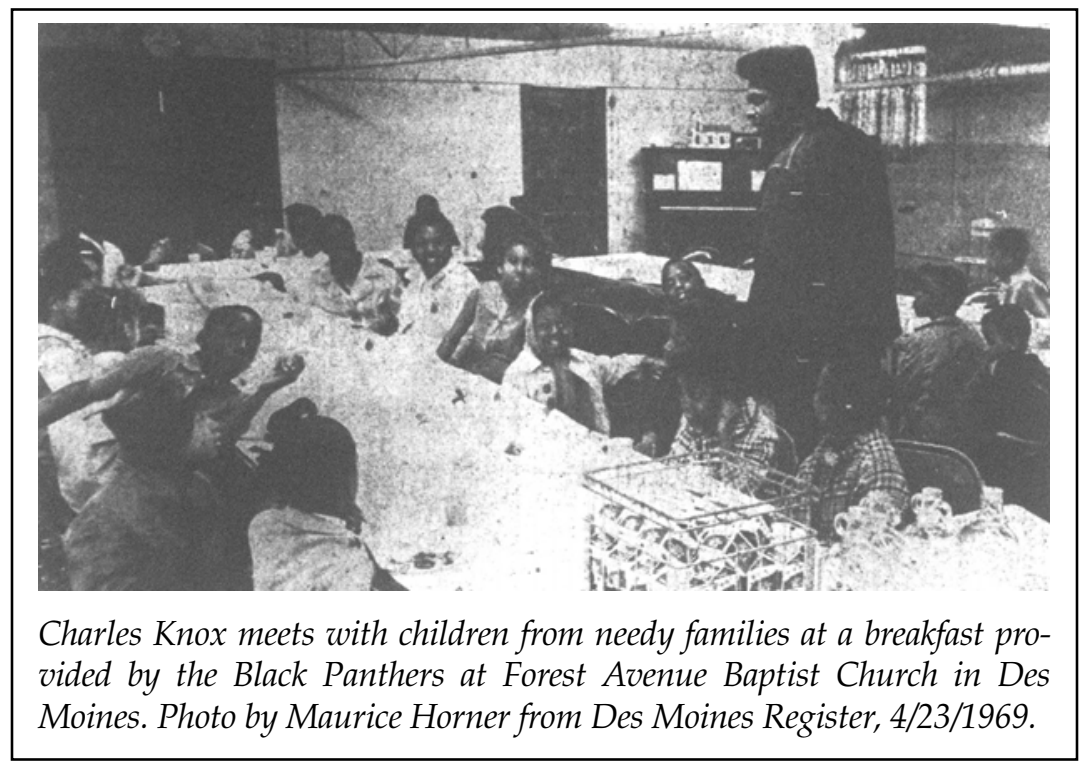

including his trial with two others for burning down the Jewett Lumber Company on Des Moines's east side.

Lesser known individuals who were vital to the Des Moines chapter also stepped forward to exert leadership within the party and the community. Nineteen-year-old Charles Smith worked as the deputy minister of defense, and Beverly Williams was the deputy minister of finance. Stephen Green was the party's lieutenant for distribution, offering goods and services to individual African Americans in particularly dire straits. Des Moines leaders organized and conducted well-attended classes on Marxism, which young high school dropouts such as Clive DePatten comprehended very well. DePatten and others employed Marxism to express to others the position of black people within the politics and economics of race and class. ${ }^{39}$

Panther chapters in Des Moines, Omaha, Milwaukee, and elsewhere mushroomed so quickly that the Oakland headquarters did not have the organizational infrastructure to exert any

38. Des Moines Register, 10/10/1968, 12/1/1968, 12/28/1968, 4/19/1969, 4/22/ 1969, 4/23/1969; Hearings before the Committee on Internal Security, 4792-97.

39. Ibid, 4792. 
real control over them. Chapter leaders responded to local conditions and fashioned strategies to address particular community problems. BPP local leadership had neither the time nor the inclination to sacrifice their own programmatic concerns for BPP headquarter's larger goals and ambitions. Des Moines Panthers took seriously the Oakland chapter's famous ten-point program, but in practice they adhered most closely to the points that were most relevant to the conditions of African Americans living in Des Moines.

Certainly Des Moines chapter leaders recognized in their city the problems of employment discrimination, police brutality, and decent housing - points 2, 4, and 8 of the national headquarters' ten-point program. The Des Moines chapter also paid a lot of attention to point 5, which demanded high-quality education for young black people. Many of the Des Moines chapter's recruits were recent high school dropouts with bad school experiences, so the chapter articulated its own 16-point program focused entirely on improving education for African Americans in Des Moines's public schools. ${ }^{40}$ That approach paid dividends as black public school students in Des Moines became openly militant in their demands for improved education. Even as Des Moines chapter members increasingly distanced themselves from Oakland Panthers, they established mutually beneficial associations with militant brethren in Kansas City and Omaha, whom they called upon for assistance and support. ${ }^{41}$

Black activists serving in other local organizations in Des Moines discovered that they could work productively with BPP members. Forty-three-year-old Joeanna Cheatom had moved to Des Moines from St. Louis during the late 1950s. Upon her arrival, she immersed herself in community affairs, becoming involved in the Black Mobile Street Workers organization. Assisted by Katherine Bryson, Cheatom and other Black Mobile Street Worker activists pushed for reforms in federal social programs such as Aid to Families with Dependent Children and other state programs that provided aid for unemployed, single

40. Anderson, "Practical Internationalists," 286-87.

41. Sister Haadasha and Charles Knox, interview with authors; Anderson, "Practical Internationalists," 284. 


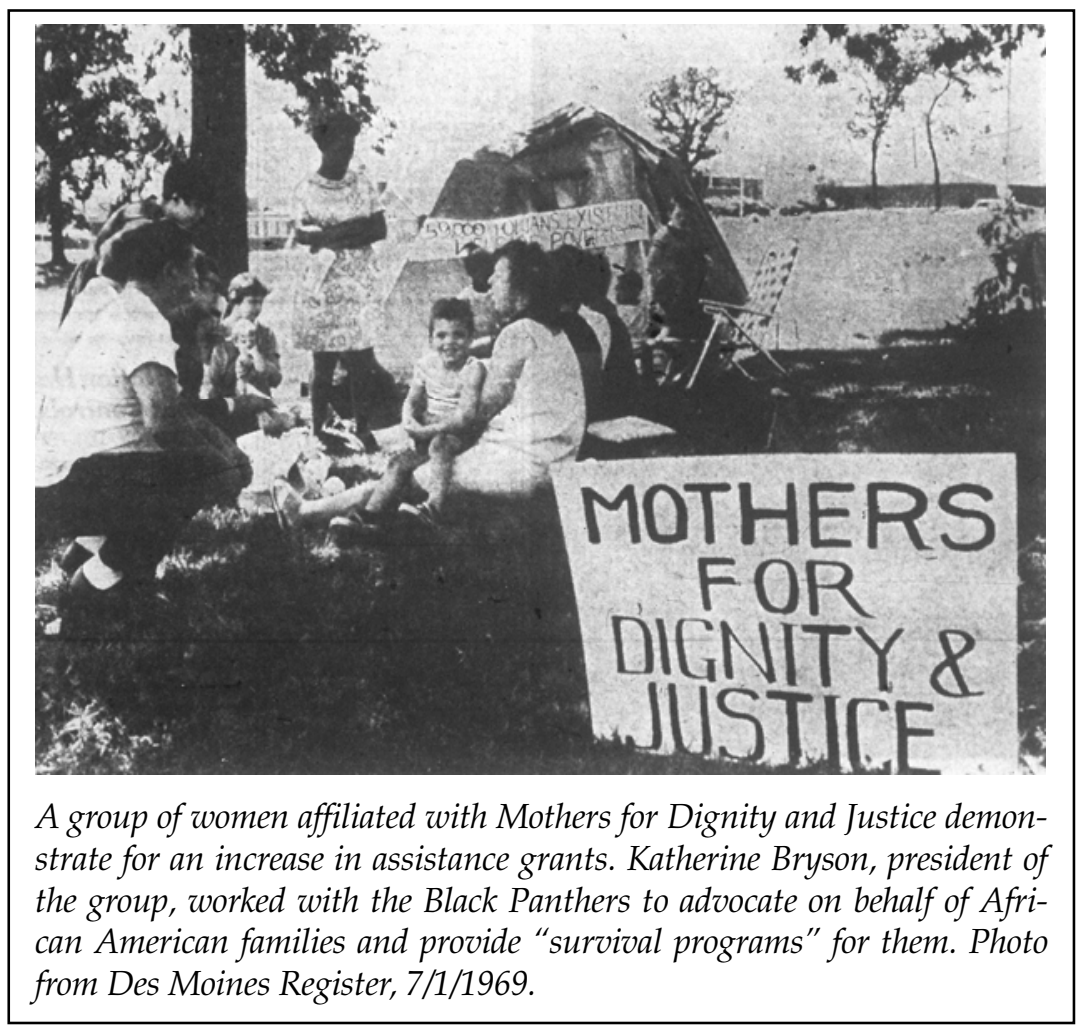

parents in the city. Cheatom also served as president of the Des Moines branch of the National Welfare Rights Organization, a group that waged vigorous campaigns on behalf of families with dependent children living in the Model Cities program area. The Model Cities program, which embraced the entire near north side community, was a federally funded, multimillion dollar program to "attack urban blight." While sharing facilities with other activists at Forest Avenue Baptist Church, Cheatom, caseworkers, and BPP leaders often gathered to discuss conditions affecting the lives of the individuals and families they served. Such encounters led to organized efforts to change conditions in the black community. For example, BPP member Gabe Taylor worked as a director of the city's Gateway Opportunities Center. Funded by the Des Moines City Council, the center disseminated employment and housing information 
to black and white working poor residents. Along with several other BPP members, Taylor and 20 other neighborhood residents boycotted and demonstrated outside of Griger's Food Market, charging that the store overcharged African Americans who shopped there. ${ }^{42}$

While responding to Des Moines's unique problems and conditions, Des Moines BPP members sold the national headquarters' newspaper, the Black Panther Intercommunal News Service, to raise funds and inform community residents about the issues of the day. Party members hawked the publication on street corners. BPP members also sold the newspaper statewide, mostly in university and college towns, including Ames, Iowa City, Cedar Falls-Waterloo, and Des Moines. The paper was also sold in Des Moines junior highs and high schools. The Intercommunal News Service's hostile expressions and revolutionary rhetoric deeply troubled white leaders and ordinary citizens of Des Moines and the state of Iowa. Many of them shared the views of William R. Scherle, a Republican who represented Iowa's Seventh Congressional District in the U.S. House of Representatives. Scherle served on the House Committee on Internal Security and collected Panther publications to use as evidence in congressional hearings on BPP activities and programs. Images of the police as pigs and violent representations of African Americans shooting police and even other black people, whom the paper called "Uncle Toms," appalled Scherle and many other whites, as well as some African Americans. ${ }^{43}$

In the summer of 1968 party members and their allies put their plans for community development into action. Mining existing community resources, for example, Rhem and others applied for federal antipoverty funds through Greater Opportunities Incorporated (GOI), a local agency, to bring an African American festival and other cultural projects to their neighborhoods. After weeks of not hearing the results of their application, about 20 party members gathered outside the Forest Hills Opportunity Center to register their displeasure with the delay.

42. Albert Gladson testimony, Hearings before the Committee on Internal Security, 4833-34; Des Moines Register, 5/10/1969, 12/28/1968; Clive DePatten testimony, Hearings before the Committee on Internal Security, 4845-46.

43. William L. Scherle Papers, State Historical Society of Iowa, Des Moines. 
"You shot us through the grease and put us through the mill," Rhem complained. "Now you close us out and tell us to wait while you make a decision affecting us. We don't want it," she argued. $^{44}$

The BPP's application had in fact drawn heated argument and considerable resistance from the GOI's eight-member executive committee, which met within the walls of the Opportunity Center. During the closed-door meeting, several African American leaders, including municipal judge Luther T. Glanton Jr., and some white members of the agency's governing body favored the project without reservation. Other executive committee members categorically rejected the proposal. A local clergyman recommended a compromise whereby the grant would be funded only if the BPP accepted guidance from a "responsible group" of volunteers. In addition, funding would occur on the basis of reimbursement, BPP projects would be subject to the agency's accounting office, and only "qualified teachers" could provide instruction in African history and culture courses offered by the party. Still others suggested postponing a decision, claiming that they did not have enough information about the project to render an informed judgment of the application's merits. One of those who supported the proposal complained, "It is ridiculous to turn down something like this for only $\$ 1,500$." Another expressed "skepticism about the project but I would like to see this board approve the plan to see what this Black Panther group will do. We hear a lot about the destructiveness of [the Black Panthers], let's see what a group can do when it asks to do something constructive." Shortly afterwards, members of the agency unanimously approved the request, granting the party $\$ 1,500$ to sponsor cultural projects along University Avenue. ${ }^{45}$

While working on program development and fund raising, party leaders, whenever opportunities arose, encouraged African Americans to participate in visible, militant actions on the streets, in schools, and in the halls of the city's municipal buildings. In the fall of 1968, many African American youngsters

44. Des Moines Register, 8/6/1968, 8/27/1968.

45. Ibid., 8/27/1968, 8/29/1968. 
in Des Moines public schools began to appear more militant, which antagonized some of their white schoolmates. On November 19, 1968, tensions between white and black students at East High boiled over into a confrontation, which included the knifing of the white student council president. When policemen arrived at the scene of the altercation, they arrested 13 students and suspended 5 others. ${ }^{46}$

The interracial violence among high school students increased hostility in the black and white communities on Des Moines's north and east sides. At a meeting called by concerned parents and teachers, held at East High at East 14th and Walker Streets, near University Avenue, some black parents encouraged others to keep their children home from school. The meeting, which Des Moines School District Superintendent Dwight Davis hoped would "improve race relations" and "bring about better understanding and unity between all white and black students," drew skepticism from both white and black parents. Instead of unifying, each group formed its own organization to advocate for its children. Meanwhile, school officials worked to punish and undercut students who wanted to keep the schools' racial problems in the public eye. Soon after the interracial fight at East High, the school board expelled four students, three from East High and one from Des Moines Technical High School (Tech High). School officials at Tech suspended between 15 and 25 white and black students after they left school in a show of support for the previously expelled students at East High. ${ }^{47}$

At that point the white school board president, George Caudill, attributed turmoil in the Des Moines schools to the agitation and militant rhetoric of the Black Panthers in Des Moines and other cities. He linked the Panthers' and black high school students' demands to the radical college campus organization, Students for a Democratic Society (SDS), which "paraphrase[ed] the Communist Manifesto with 'students of the world unite.'" In anticipation of possible "walk outs, sit-ins, and open con-

46. Ibid., 11/22/1968.

47. Ibid., 11/22/1968, 12/4/1968, 12/12/1968. The December 12 Register article noted that black and white parent groups formed with different visions of school problems and solutions. 
flict," the school board adopted "strict disciplinary policies to cope with such events." ${ }^{\prime 8}$

On December 3, three days after the student walkouts, 450 presumably white citizens met at the Bellizzi-MacRae American Legion Post hall and organized the Concerned Parents Association. Dwight Hummell, the new organization's spokesperson, assured the Des Moines Register that the association was "not a white backlash group and not racist." Through the Register, Hummell "invited Negroes to join the association," which those at the Legion hall had organized to express, among other "concerns," that "school officials have discriminated against good students by inviting preferential treatment to the habitual trouble makers." The organization went before the school board to express support for the board president's determination to exert discipline in the schools and expel, not just suspend, students guilty of serious violations of the board's newly strengthened disciplinary policy. ${ }^{49}$

During fall 1968 and spring 1969, as racial tensions intensified in Des Moines schools and elsewhere, Charles Knox became the militant face of the Des Moines Black Panther Party. Knox first came to prominence when, on October 10, 1968, a spectacular fire destroyed the Jewett Lumber Company on Des Moines's east side. Five African Americans, including Knox, Joeanna Cheatom, and the latter's 16-year-old son Marvin, were arrested and charged with setting the fire. Furthermore, while he was still under indictment for arson in the Jewett Lumber case, police arrested Knox in Good Park on April 13, 1969, for defying orders to stop speaking over a portable address system. On that day Knox and other BPP members had attended a rally at the park to promote a free breakfast program for impoverished children of the near north side neighborhood. ${ }^{50}$

The rally proceeded smoothly, and nearly came to a close, when about 12 police officers moved in to arrest participants on charges of unlawful assembly and resisting arrest. Des Moines police sergeant Ed Harlan told reporters that when police ar-

48. Ibid., 12/4/1968.

49. Ibid.

50. Ibid., 10/10/1968, 4/14/1969, 4/22/1969. 
rived at Good Park, Knox "turned his attention to the officers and advised the crowd to 'rise up and strike out' and to turn on the Des Moines pigs." As police moved to arrest Knox, BPP member Charles Edward Smith came to the aid of his fellow Panther by trying to pull Knox from the clutches of arresting officers. At the same time, boisterous groups moved down University Avenue, hurling rocks and bricks at squad cars and passing vehicles, smashing windshields in the process. ${ }^{51}$

By nightfall, University Avenue had taken on features of a war zone, with Forest and University avenues closed to traffic and patrolmen stationed at every corner. When the fracas ended, a young black woman was taken to a hospital after sustaining gunshot wounds in the shoulder. Several of those returning home from the Good Park rally were beaten and arrested. Evelyn, Clive, and Hobart DePatten Jr. were among the battered and bruised. As Hobart DePatten Sr. recalled, "They arrested my son Clive, and then my other son, Hobart Jr., when he protested the arrest of Clive. When my wife, Evelyn, asked police what was happening, they arrested her too. If I hadn't been inside my house, they would have arrested me, too." This experience with police had a profound impact on Clive DePatten. While confined in the Polk County jail - after being treated at a nearby hospital, returned to police headquarters, and charged and booked - he joined the Black Panther Party. He soon immersed himself in party organizing and became a program training counselor at Soul Village, an institution sponsored by the United Black Federation. ${ }^{52}$

Mayor Thomas Urban tried to quell black community unrest by holding a special meeting on April 15, 1969, to discuss problems contributing to the most recent Good Park riot. Among those who attended the gathering were members of the Des Moines Police Department, BPP leaders, Model Cities officials, and approximately 30 residents from the near north side neighborhood. During the meeting, citizens demanded to know why police were on hand at the rally since there was no threat

51. Des Moines Register, 4/30/1969.

52. Ibid., 4/14/1969 (quote), 10/15/1970; Hearings before the Committee on Internal Security, 4812. 
of violence. Police Chief Nichols and Detective Ed Rand claimed that police moved in only after receiving calls from residents near Good Park, who complained that Knox and other BPP leaders were using obscene language during the gathering. After several heated exchanges between city officials and Panther leaders, the meeting ended when Urban refused Knox's request that an officer actually present at the scene appear before the group to explain police actions. ${ }^{53}$

While Urban was trying to foster communication between the Des Moines police force and the African American community, the Black Panthers garnered increasing support from black students and white allies in Iowa's colleges and universities. Black Panther leaders accepted invitations to appear on campuses, sometimes visiting classrooms to discuss their purposes and programs. ${ }^{54}$ Two days after the April 1969 Good Park rally and ensuing riot, nearly 100 people, mostly students from Iowa State University and the University of Iowa, assembled in Iowa City on the east steps of Old Capitol, the University of Iowa's signature building. Many voiced support for the BPP members who had been arrested following the rally. Also in attendance were members of the Iowa City Peace and Freedom Club and the Des Moines branch of the Students for a Democratic Society. Speakers at the Iowa City rally claimed that the arrests of BPP members in Des Moines were intended to turn the public against the BPP. Over the next few days, University of Iowa students led a wave of demonstrations at the Des Moines courthouse, registering their displeasure with the actions taken by the city's police department. ${ }^{55}$

Against the backdrop of the Jewett lumber yard fire, the arson trial, demonstrations, riots, and arrests, the situation in Des Moines suddenly turned even more violent. On April 14 someone set off an explosion on the near north side, apparently intending to topple a telephone pole into an electrical substation. Then, around midnight on April 26, 1969, a terrible explosion leveled the entire back end of the BPP headquarters, shattering

53. Des Moines Register, 4/14/1969.

54. Clive DePatten testimony, Hearings before the Committee on Internal Security, 4810 .

55. Des Moines Register, 4/22/1969. 


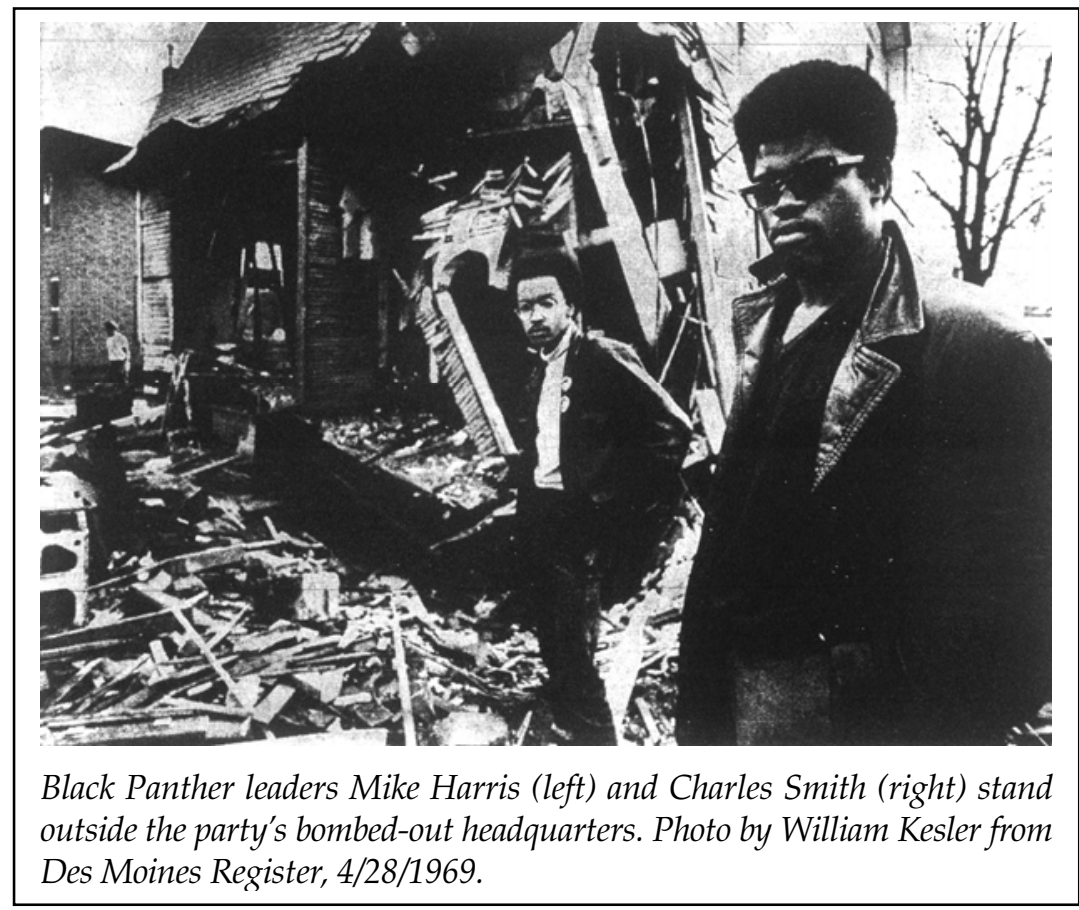

windows in at least 50 homes in the neighborhood. As Panthers Edward King and Johnson Hughes were leaving the demolished eight-room facility, they fought with police officers who had attempted to spray them with mace. Police arrested both men and charged them with interfering with the duties of a police officer and resisting arrest. Bedlam ensued as groups of angry black residents stormed into the streets heaving gasoline-filled Molotov cocktail bottles and rocks at police and parked cars. The next morning the sun rose on scores of anxious police officers armed with riot guns sealing off access to the Panther house and the police station downtown to prevent the possibility of further bombings. ${ }^{56}$

In the following days and weeks, mutual suspicions intensified between local blacks and the police. Many African Americans were convinced that the police knew the dynamiters' identities and that some officers at least conspired in the bombings.

56. Des Moines Register, 4/27/1969, 4/28/1969. 
Panther member Charles Smith reported that on the night the headquarters was destroyed police arrived at the scene moments after the explosions. "They were at our door thirty seconds after the explosion," he recalled. "I've never seen them get anywhere that fast in my life." Police and city officials, for their part, accused Panther members of bombing their own headquarters. Albert Gladson, a Des Moines police intelligence officer, alleged that "approximately two weeks after the bombing of the Panther headquarters, Clive DePatten, Michael Smith, and one other party member spoke before a group in Minneapolis, Minnesota, and openly admitted that they had exploded a device to blow up their own headquarters to gain national recognition for the Black Panther Party."

HISTORICALLY, in the United States and elsewhere, governments' violent repression (legal or extralegal) has successfully disrupted formal organizations seeking fundamental political and economic change. Violence, combined with mainstream political leaders' desire to punish Black Panthers, administered the coup de gras to the Des Moines chapter of the Black Panther Party for Self-Defense. By early 1970, with headquarters blown to smithereens and party leaders, especially Knox, facing court charges, the party dissolved. Soon after the chapter's dissolution Knox organized the Revolutionary Communist Youth in Des Moines. Soon thereafter, white leaders lodged vociferous protests when, in October 1970, Larry Scales, director of Iowa Children's and Family Services, hired Knox, at a salary of \$7,000 per year to counsel juvenile delinquents in the Model Cities Program. Scales hired Knox because he was "impressed" with Knox's "confidence, concern and ability in working with black youth." U.S. Representative William Scherle, from his position on the House of Representatives' Internal Security Committee, requested a federal investigation to determine how a person with Knox's background and political views could be hired by a federally funded program to work with young people. ${ }^{58}$

57. Des Moines Register, 4/28/1969; Albert Gladson testimony, Hearings before the Committee on Internal Security, 4833.

58. Des Moines Register, 10/14/1970. 
In 1970 the House Internal Security Committee conducted hearings on the threat the Black Panthers posed to the security of the United States and its citizens. Consisting primarily of congressmen from southern and midwestern districts, the committee was charged with "investigating the activities and objectives of the national office of the Black Panther Party." It also tried to determine whether the pronouncements voiced by party officials or the material printed in The Black Panther was merely rhetorical or if the Panthers actually advocated strategies to overthrow the government of the United States. ${ }^{59}$

In many instances the testimony that committee members heard about Des Moines BPP activities consisted of rumor, innuendo, and speculation intended to reinforce their preconceived notions of the party as a violent organization. ${ }^{60}$ In an overt effort to create an image of the party as a militant organization that advocated armed violence, committee witnesses tended to associate violent incidents in Des Moines with the fiery, outspoken Charles Knox. According to Congressman Scherle, Knox "had a long and shady history of involvement with the wrong side of the law, and an equally long and open career with revolutionary groups including the Black Panther and Communist Parties." In light of Knox's background and activities, Scherle argued, "The people of Iowa will not let this issue lapse into oblivion. They have the right to expect their representatives in government to use their influence to root out extremists from Iowa antipoverty programs." ${ }^{61}$

59. The committee was cochaired by Richard Ichord (D-MO) and Richardson Preyer (D-NC); its members included Claude Pepper (D-FL), Edwin Edwards (D-LA), Louis Stokes (D-OH), John Ashbrook (R-OH), Richard Roudebush (RIN), Albert Watson (R-SC), and William Scherle (R-IA).

60. House Resolution 7, Hearings before the Committee on Internal Security, iv-v.

61. Hearings before the Committee on Internal Security, 4833, 4862-63. The hearings were, in fact, intended largely to discredit federally financed antipoverty programs in metropolitan areas. More often than not, however, committee members engaged in antics that tended to call greater attention to economic and political inequities that poor black and white residents experienced in urban centers. The conservative backlash against Great Society initiatives received treatment in Daniel P. Moynihan, Maximum Feasible Misunderstanding: Community Action in the War on Poverty (New York, 1969); A. James Reichley, Conservatives in an Age of Change: The Nixon and Ford Administrations (Washington, DC, 1981); Gareth Davies, From Opportunity to Entitlement: The Transforma- 
In fall 1970, while Scherle and his colleagues were conducting hearings on the Black Panthers, Knox converted his arrests into opportunities to engage in what anthropologist Victor Turner called performances of political theater. ${ }^{62}$ Often the charges against Knox stemmed from open displays of contempt for Iowa law enforcement officials. For example, on November 5, Des Moines city police arrested Knox on a charge of operating a motor vehicle with a suspended license. When he appeared in court later that afternoon, however, Knox faced far more serious legal action after failing to acknowledge Judge Ray Harrison in the Des Moines Municipal Court. Upon hearing the charges against him, Knox refused legal counsel but not before proceeding to call the judge "a pig fascist" and John King, the Polk County assistant district attorney, a "degenerate punk." As a result of Knox's contempt, the judge committed him to five days in the county jail. At a subsequent contempt trial, when the judge asked Knox if he wished to testify on his own behalf, Knox stated, "For what? I tell you, man, if I'm guilty of anything I'm guilty of serving the people and that's all I need to say and nothing more." "You can jail a revolutionary, but you can't jail a revolution," he was overheard muttering to the judge as he was being led from the courtroom. During the trial, Clive DePatten, Steven Green, and Mary Rhem were also charged with contempt after staging demonstrations while the court was in session and shouting epithets such as "fascist court" and referring to the officers as "pigs." On April 9 of the following year, each stood trial for contempt and received sentences ranging from 90 days to six months in the county jail. ${ }^{63}$

In spite of Panther political theater and protests from Congressman Scherle and his colleagues against hiring black radicals for federal positions, former Des Moines Panthers, over the next several years, secured political positions or conventional jobs

tion and Decline of Great Society Liberalism (Lawrence, KS, 1996); and Philip A. Klinkner with Rogers M. Smith, The Unsteady March: The Rise and Decline of Racial Equality in America (Chicago, 1999).

62. Victor Turner, From Ritual to Theatre: The Seriousness of Play (Baltimore, 1982), 115-16.

63. Clive DePatten vs. Ray Harrison; Steven Green vs. Ray Harrison; and Mary Rhem vs. Ray Harrison, in Northwestern Reporter, 2d ser., vol. 185 N.W. (2d Cir. 1971). 
serving the black community. Looking back 40 years later, historian Ralph Crowder, who grew up on Des Moines's near north side, expressed surprise to recognize names of African Americans who emerged after 1967 as leaders in his old community. With the emergence of the Black Panther Party, Crowder wrote, many "working-class blacks in D[es] M[oines] [attained] a voice that was usually never heard." These new voices challenged "traditional middle class Black leadership that dominated not only DM but other communities where the Panther Party thrived." "The transformation of some local people I knew," Crowder remembered, was "truly amazing.." ${ }^{64}$

Those new voices and transformed individuals included Clive DePatten, who had testified before the Committee on Internal Security and later served the black community as manager of the KUCB radio station. Until death of heart failure on November 14, 1996, at age 46, DePatten, who changed his name to Kalonji Saadiq, often represented African Americans before the Des Moines City Council. He was especially vocal "in his relentless bitter criticism of the Des Moines police department." ${ }^{\prime 65}$ Mary Rhem, now Sister Haadasha, founder of the Des Moines BPP, works for Oakridge Neighborhood Services serving poor people, most of them African American, on Des Moines's near north side. Stephen Green, who took the name Ako AbdulSamad, organized or worked with a number of organizations serving poor and black people. As representative of Des Moines's near north side neighborhood in the state legislature, he has worked on issues of particular concern to African Americans, such as Iowa's terribly disproportionate incarceration rates of blacks. ${ }^{66}$

The political, cultural, and social legacy of the Des Moines chapter of the Black Panther Party remained evident in many Des Moines institutions. The legacy was recognizable by African Americans and some whites who, while uncomfortable with black power rhetoric and Black Panther political histrionics, acknowledged that the party's programs, demonstrations,

64. Ralph Crowder to Bruce Fehn.

65. Des Moines Register, 12/27/1996, 11/15/1996.

66. The Iowa Independent, 10/24/2007, at http://iowaindependent.com, last accessed 8/23/2008. 
and posturing spurred the city toward more equitable employment of black citizens, whereas city officials had not previously responded to mainstream African American leaders' repeated calls for program funding and services in the black community. As early as 1969, Des Moines high school students could take courses in black history, and those with special learning needs could attend the Frederick Douglass School, established in 1972. Police officers never again could abuse a prisoner without risking the wrath of black community members such as Kalonji Saadiq, the former Clive DePatten. As for Joeanna Cheatom (who, along with her 16-year-old son Marvin and the irrepressible Charles Knox, was arrested for setting fire to the Jewett Lumber Company), after her death on May 2, 1984, at age 52, city officials named a city park for her. Joeanna Cheatom Park is located in the near north side community, just a few blocks from Good Park, where so much of Black Panther history in Des Moines rushed forward. 